\title{
The Importance of Resources and Security in the Socio-Economic Integration of Refugees. A Study on the Impact of Length of Stay in Asylum Accommodation and Residence Status on Socio-Economic Integration for the Four Largest Refugee Groups in the Netherlands
}

\section{Linda Bakker • Jaco Dagevos • Godfried Engbersen}

\begin{abstract}
In many European countries, including the Netherlands, refugees stay in asylum accommodation pending a decision on their asylum request. While it seems evident that the lack of resources and insecurity about the future experienced during this stay will impact refugees' subsequent ability to integrate with the host society, so far this has hardly been studied in an extensive way. Also, the type of residence status granted can be a source of insecurity that impacts their integration. Previous studies on refugee integration have already shown the impact of pre-migration stressors such as traumatic experiences on mental health and integration. In this study, we use a large-scale dataset containing detailed information on about 4,000 refugees to show that also postmigration stressors affect mental health and hinder the socio-economic integration of the four largest refugee groups in the Netherlands: Afghan, Iraqi, Iranian and Somali.
\end{abstract}

Keywords Refugee - Integration · Asylum accommodation · Residence status · Mental health

\section{Introduction}

Integration is an essentially contested concept; no single, generally valid definition has been agreed upon so far (Castles et al. 2002). Nevertheless, a common view on

L. Bakker $(\bowtie)$

Faculty of Social Sciences, Sociology, Erasmus University Rotterdam, P.O. Box 1738

3000 DR Rotterdam, The Netherlands

e-mail: 1.bakker@fsw.eur.nl

J. Dagevos

The Netherlands Institute for Social Research, The Hague, The Netherlands

G. Engbersen

Sociology Department at the Erasmus University Rotterdam, Rotterdam, The Netherlands 
the concept can be deduced from the rich body of literature, in which integration is seen as a multidimensional two-way process that starts upon arrival in the host state. This process requires from immigrants a willingness to adapt to the lifestyle of the host community (Ager and Strang 2008; Castles et al. 2002; Lomba 2010; Mestheneos and Ioannidi 2002; Phillimore 2011), and from the host country a willingness to facilitate integration (i.e. access to jobs and services) and an acceptance of the immigrants in social interaction (Castles et al. 2002). As this process is seen to start upon arrival rather than as representing a destination point, this implies that early experiences can influence long-term outcomes (Castles et al. 2002; Lomba 2010). We will use this understanding of integration as a starting point to study refugee integration in the Netherlands.

Refugees are an interesting migrant group to study since they are considerably different from labour migrants due to a different migration motive and history (Feller 2005; Phillimore 2011). As stated in the Geneva Convention, the United Nations defines a refugee as: "a person who is, due to a well-founded fear of being persecuted for reasons of race, religion, nationality, membership of a particular social group or political opinion, outside the country of his nationality and is unable or, owing to such fear, is unwilling to avail himself of the protection of that country". This background is argued to affect the integration process in the host country of refugees. Indeed, traumatic experiences in the country of origin and during the flight have been shown to have an impact on mental health, which subsequently may hinder integration (Beiser 2006; Jorden et al. 2009; Laban et al. 2004; Phillimore 2011; Takeda 2000).

Besides pre-migration stressors, several authors propose that post-migration factors may also affect refugee integration (Phillimore 2011; Ryan et al. 2008). The reception in the host country is a vital part of the post-migration experience. Therefore, the asylum procedure or more properly the asylum accommodation and the eventually granted residence status are considered key issues in refugee integration. The choice for these two post-migration stressors accords with our definition of integration. Since we understand integration as a multidimensional two-way process, we shall not only analyse the achieved socio-economic position of refugees to explain their integration process, but will focus specifically on the impact of these two postmigration stressors (length of stay in asylum accommodation and their granted residence status) which are rooted in the receiving society.

Using Hobfoll's (2001) theory on resources and stress, we explain how postmigration stressors can hamper refugee integration. In the first place, we will argue how a stay in asylum accommodation and the granted residence status can function as constraints on refugees' ability to (re)gain the necessary resources for successful integration. Second, we will argue how refugees' mental health is affected by these two post-migration stressors and how this can affect refugee integration. Phillimore (2011) already showed the importance of mental health in refugee integration. Those refugees that were diagnosed with a mental health problem struggled to engage in activities that might lead them to integrate, ranging from seeking employment to developing relationships with the local population. Our central research question is thus: How and to what extent do post-migration stressors affect mental health and subsequently the socio-economic integration of the four largest refugee groups in the Netherlands? The answers to these questions are crucial to understanding the role of the current Dutch asylum policy (regarding accommodation and residence status) in facilitating refugee integration. As the asylum procedure in the Netherlands is lengthy 
and several residence statuses can be granted, marked by different sets of rights and certainty (Kofman 2002; Morris 2003, 2012), this makes an interesting case study.

We focus on the four largest refugee groups in the Netherlands: Afghan, Iraqi, Iranian and Somali refugees whose asylum request has been approved. We use survey data $(N=3,950)$ gathered by the Netherlands Institute of Social Research (SCP) (Dourleijn and Dagevos 2011), which contains extensive information on refugees' flight to the Netherlands, current participation, identification and more. We concentrate this study on refugees with a flight experience who awaited the decision on their case in asylum accommodation. This rich dataset enables us to quantitatively assess relations between integration, post-migration stressors and mental health.

In the following, we will first discuss the central concepts and the Dutch asylum context, and propose a theoretical model on the relations between post-migration stressors and socio-economic integration. The research population and the different migration histories of the four refugee groups under study are also described in more detail. We conduct Structural Equation Modelling in Mplus in order to test the formulated hypotheses. The benefit of this method over simple regression is that the estimates are computed for the model as a whole; the reliability of the results is therefore higher. Clearly, the outcomes of this study will also be relevant to other Western European societies who receive refugees and are seeking their successful integration in society.

\section{Socio-Economic Integration}

Having defined integration as a multidimensional two-way process that starts upon arrival in the host state, we need to make a distinction between different dimensions of integration. Esser (2004) distinguishes four dimensions of integration. The first, Kulturation, involves the acquisition of knowledge and skills (e.g. the language of the host country) in order to successfully find their way around the host society. Platzierung refers to the position immigrants come to have in terms of social stratification, which is mainly determined by their achievements in employment, education and housing. Participation in societal institutions thus is a key aspect. Interaktion refers to the extent of interethnic social contacts established with, for example, friends, neighbours and even a spouse. The emotional aspect is more prevalent in this dimension. Lastly, Identifikation gives an indication of the emotional bonding with the host country. Esser states that this can only be established if the other three dimensions are met, at least to a certain extent.

Generally in Dutch literature, a distinction is made between structural or socioeconomic integration and socio-cultural integration. The first dimension is similar to Esser's Platzierung and is understood as the degree to which migrants participate in key societal institutions, such as the labour and housing market, the educational system and the political sphere (Engbersen 2003). Especially their position on the labour market is viewed as a crucial indicator of integration (Snel et al. 2006; Vermeulen and Penninx 2000). The second dimension is defined as: the social contacts that members and organisations of minority groups maintain with society as a whole, and the cultural adaptations to that society (Dagevos 2001; Vermeulen and Penninx 2000). In this study, we will focus on the first dimension of integration, in particular on their labour market position. We thus study refugees' employment status, occupational status and social benefits dependency. 


\section{Refugee Integration: Resources and Stress}

In former migration and refugee studies, demographic factors (i.e. length of stay, age of migration and education in the home and host country) turn out to be important predictors of successful socio-economic integration (Blom 2004; Potocky-Tripodi 2003; Waxman 2001). As said, traumatic experiences in the country of origin and during the flight are shown to have an impact on refugees' mental health and subsequently on their integration process (Beiser 2006; Jorden et al. 2009; Laban et al. 2004; Phillimore 2011; Takeda 2000). Berry et al. (1987) were among the first to highlight the importance of acculturative stress: 'the reduction in health status of individuals who are undergoing acculturation'. They show that not only pre-migration but also post-migration experiences (i.e. adaptation or integration in a host state) cause stress.

Hobfoll (2001), in his theory of conservation of resources, defines stress from a resources perspective. In this perspective, stress can be due to the threat or actual loss of resources, but also to a failure of investment to produce expected returns. He makes a distinction between personal, material and social resources. Personal resources can be physical or psychological, such as health and personality traits. Examples of material resources are money and property. Social resources refer to the benefits of personal relationships. A fourth type that can be added to this typology is cultural resources. These are skills, knowledge and beliefs that are learned in a particular cultural setting, such as language and occupational skills (Ryan et al. 2008).

These distinctions are highly relevant to understanding refugee integration. First, an actual loss of resources occurs due to the flight. Material as well as social and cultural resources from the origin country cannot be transferred to the host country, for instance social contacts and language skills. In order to integrate in the host society, they need to (re)gain such resources (Hobfoll 2001). Second, the post-migration experience in the host country can be disappointing when refugees fail to achieve the expected returns, which in turn can inflict mental health problems. We will discuss both types of stress in relation to refugees' socio-economic integration and then formulate our hypotheses.

\section{Asylum Procedure: Constraints for (Re)gaining Resources}

In the process of (re)gaining resources, two types of constraints can be identified: personal and environmental constraints. Personal constraints include cultural values and beliefs that hinder certain actions. For example, traditional gender roles might hamper women's participation in the labour market, and certain religious or cultural beliefs might act as a barrier for intercultural contacts (Hobfoll 2001). In this paper, we will however focus on two potential environmental constraints (i.e. post-migration stressors). The first is refugees' stay in asylum accommodation. In the Netherlands, asylum seekers must stay in asylum centres pending a decision on their asylum request. In the year 2001, a new Aliens Act was adopted with the main aim of shortening the asylum procedure. Prior to the 2001 Aliens Act, it could take years to reach a final decision on an asylum request. Today, $82 \%$ of the asylum requests are processed within the set period of 6 months. ${ }^{1}$ In order not to create false hope, asylum seekers are discouraged from integrating in Dutch society as long as the asylum

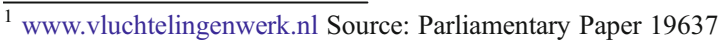


procedure is in process. This approach is revealed in several aspects of asylum accommodation.

First, the centres are often situated in rural areas, which serves as an obstacle to active participation in the local community. One is free to move outside the asylum centre but still needs to report regularly. Second, asylum seekers have only limited access to the (formal) labour market (in 2008 this was expanded from 12 weeks to 24 weeks a year), and no access to education ${ }^{2}$ or social security. During the asylum procedure, their basic needs are provided for by the state (based on 'bed, water and bread' and $€ 43$ per adult person per week). ${ }^{3}$ Last, all aspects of life are conducted in the same place, and all activities are tightly scheduled and controlled. As daily activities take place in the immediate company of a large group of others, privacy and autonomy are limited (De Haan and Althoff 2002).

We argue that a lengthy stay in such an environment, where social interactions with the outside world are limited and personal development is restrained, hinders refugees' ability to (re)gain the resources they need to integrate in the labour market once their asylum request has been granted. Having a job is vital with a view to obtaining material resources, but also to developing social networks and language skills (social and cultural resources) (Jahoda 1982). We thus expect that the length of stay in an asylum centre will have adverse effects on the socio-economic integration of refugees (H1). De Vroome and Van Tubergen (2010) showed that especially human capital (i.e. Dutch language proficiency, host country education and work experience in the Netherlands) is negatively affected by a lengthy stay in asylum centres, which in turn hampers socio-economic integration.

A second potential environmental constraint for regaining resources is the granted residence status. Since 1 April 2001, every asylum seeker who is granted permission to stay in the Netherlands receives a temporary permit for a maximum of 5 years. During this period, they need to acquire a qualification of integration ${ }^{4}$ in order to apply for a permanent status after 5 years. Prior to 2001, various asylum statuses were granted to refugees with different sets of rights depending on the grounds of asylum. It was also possible to receive a permanent status on arrival. The abolishment of this option is indicative of the current stricter asylum policy.

Uniform rights and privileges are attached to both the temporary and permanent status with regard to employment, education and social benefits. However, one important disadvantage of the temporary status is that institutions might be reluctant to grant services, for example mortgages, to refugees with that status. ${ }^{5}$ Such hindrance by institutions to settling in the Netherlands can be argued to harm integration.

\footnotetext{
${ }^{2}$ Asylum seekers aged 18 or over must reside legally in the Netherlands if they wish to enroll for a study. This means that they should either have a residence permit or should be in procedure for a residence permit with permission to await the decision in the Netherlands. Under-age children are entitled to education in the Netherlands until their 18th year. Admission to education does not depend on legal residence in the Netherlands.

${ }_{3}^{3}$ Every asylum seeker in a centre is entitled to a weekly financial supplement for food, clothing, and other personal expenditure items. (RVA 2005 article 14, http://wetten.overheid.nl/BWBR0017959/geldigheidsdatum 15-06-2009). The financial supplement depends on the extent to which the asylum seeker must provide for his or her own food. In a centre where the residents are fully responsible for their own food, this supplement is as follows (mid 2009): adults: $€$ 55.16, children until age 11: $€ 35.38$, children older than 11 and younger than $18: € 42.37$, and single under-age aliens: $€ 51.72$. Single parents receive an additional supplement of $€ 28.45$.

${ }^{4}$ Language proficiency and knowledge of Dutch society are central to this qualification.

${ }^{5}$ Commission of Equal Treatment [Commissie Gelijke Behandeling]. In: Tijd en Asiel, Terlouw and Zwaan 2011.
} 
Therefore, we expect that having a refugee status (compared to having Dutch citizenship) has a negative effect on refugees' socio-economic integration (H2a). We expect this effect to be stronger for those who have a temporary residence status $(H 2 b)$. Compared to the permanent residence status, having the Dutch nationality gives refugees the right to vote and to travel freely.

\section{Asylum Procedure: Impact on Mental Health}

Besides the barriers to material, social and cultural resources for successful integration, we argue that the identified post-migration factors also affect refugees' personal resources, understood in this paper as mental health. Health is considered a prerequisite for regaining the other types of resources. Therefore, we argue that mental health serves as a mediator between the post-migration stressors and socioeconomic integration. The duration of stay in an asylum centre represents fear of being deported and uncertainty as to the duration and outcome of the procedure (Laban et al. 2004). Insecurity about the future during the asylum procedure might impair people's ability to recover from posttraumatic stress and to integrate in society once asylum has been granted (Ghorashi 2005; Lomba 2010). The restricted rights during the asylum procedure might moreover create unnecessary dependence and reduced confidence, causing a majority of asylum seekers to lose their motivation for a new start after years of frustration (Ghorashi 2005; Ryan et al. 2008). It is quite probable that a lengthy stay in asylum accommodation fosters a passive attitude, making integration a difficult task in the long run. They no longer feel in control over their own life; their future prospects are in the hands of the institution or the state. Ghorashi (2005) sums up the situation as follows: "Seclusion and forced passivity combine to waste away the first and most important years of their lives in exile" (pp. 190-191). Moreover, the lack of privacy in an asylum centre (e.g. everyone has about $5 \mathrm{~m}^{2}$ of living space) can exacerbate (mental) health problems. Thus, we hypothesise that the length of stay in asylum accommodation has a negative effect on refugees' mental health, which hampers their socio-economic integration (H3).

Although there is a lack of focused discussion and research on the relationship between (temporary) protection and integration (Castles et al. 2002), a similar argument can be made for the granted residence status. A temporary status can be withdrawn once the situation in the country of origin improves, requiring the refugee to leave the Netherlands and return home. It should be noted that this seldom occurs in practice; if refugees are not allowed to stay in the Netherlands, they either migrate on to another country or end up in illegality (Terlouw and Zwaan 2011). Still, having a temporary residence status is likely to impair the ability to look forward to the future, which can cause mental health problems. Momartin et al. (2006) already demonstrated how a temporary status can negatively affect the mental health of Afghan and Iranian refugees in Australia. Thus, we expect that having a refugee status will have a negative effect on refugees' mental health, which can hinder their socioeconomic integration (H4a). We expect this effect to be stronger for those who have a temporary residence status (H4b). Within the theoretical model (Fig. 1), we thus make a distinction between direct and indirect effects of post-migration stressors on the socioeconomic integration of refugees. 


\section{Research Population}

The refugee population under study together constitutes $8 \%$ of the non-western population in Dutch society. ${ }^{6}$ The majority fled to the Netherlands for fear of personal persecution and (civil) war. Others have come to the Netherlands for family migration, work or study purposes (Dourleijn and Dagevos 2011). The nature of the migration (flight) is thus what these groups have in common. However, their migration history and socio-demographic background vary widely (Table 1).

Of the four refugee groups under study, the Iranian refugees were the first to come to the Netherlands, soon followed by the Iraqi refugees, mostly Kurds. The second wave of refugees from Iraq arrived during the 'war on terrorism', as the Netherlands offered 'categorical protection" 7 . Somali refugees came to the Netherlands in the early 1990s. Some migrated on to England where the Somali community is larger and where the labour market is thought to offer more opportunities for refugees. The severe situation in Somalia again increased migration to the Netherlands in the period 2005-2009. Afghans arrived in the late 1990s due to the strict Taliban regime.

\section{Data and Analyses}

Data

To test the formulated hypotheses, we will use the SING $2009^{8}$ dataset collected by the The Netherlands Institute for Social Research. This cross-sectional dataset contains information on different dimensions of integration of the four largest refugee groups in the Netherlands: Iraqi, Somali, Iranian and Afghan. A random sample was drawn, in collaboration with Statistics Netherlands (CBS), from the Municipal Population Register (GBA). For each group, about 1,000 structured face-to-face interviews were conducted. To also reach those not yet able to speak Dutch, bilingual interviewers were used for interviews with refugees who have been in the Netherlands for less than 5 years. Almost half of the sampled Afghan (49\%) and Iraqi (48\%) group participated; the response rate in the other groups was slightly lower, with $44 \%$ for the sampled Iranian group and $38 \%$ for the Somali group. ${ }^{9}$ In this study, the determination of ethnicity is based on the country of birth.

The sample population consists of refugees with a granted status in the age of 15 and up $(N=3,950)$. Since we are only interested in refugees with a flight experience and motive, we excluded the second-generation refugees $(n=91)$, as well as refugees

\footnotetext{
${ }^{6}$ Statistics Netherlands distinguishes between western and non-western countries. Western countries are all European countries including Central and Eastern Europe (except Turkey), North American countries, some Asian countries (Japan and Indonesia) and the countries in Oceania (Australia and New Zealand). Turkey and all countries in Latin and South America, Africa and Asia are considered non-western.

${ }^{7}$ Usually, asylum requests are assessed individually, but if the situation in a certain country is considered extremely dangerous, categorical protection is offered to all refugees coming from that particular country or region. Asylum is thus granted on common grounds instead of for individual reasons, but just for a limited period of time.

${ }^{8}$ Survey Integratie Nieuwe Groepen, gathered in 2009. For more information on the fieldwork see Dourleijn (2010).

9 This also means that the non-response is about $50 \%$ per group. The distribution of age and gender in the sample differs slightly from the population. For example, Somali men are underrepresented, as well as youngsters (in the age of 15-34) in the Afghani, Iraqi and Iranian group; therefore, a weight was included.
} 


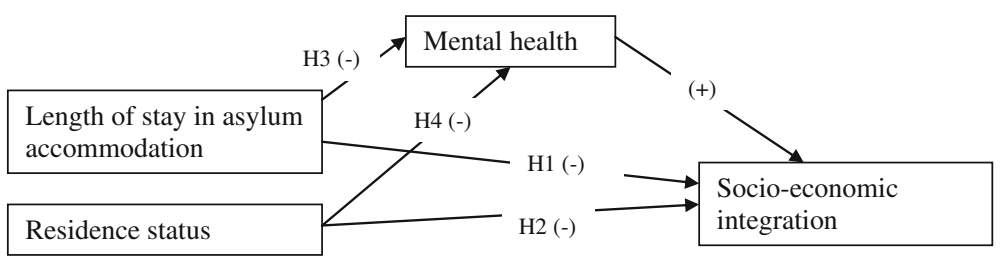

Fig. 1 Theoretical model of the effects of length of stay in asylum accommodation and residence status on socio-economic integration of refugees

who came for work and study purposes $(n=231) .{ }^{10}$ Also, we excluded those who did not stay in asylum accommodation but with their partner, family or friends following their arrival in the Netherlands $(n=624)$. This group is inherently different from our research population because they often followed a family member and thus did not experience flight stress or insecurity. Lastly, we excluded respondents over 65 years old $(n=97)$ on account of our focus on the potential working population. The final sample is thus representative for the entire refugee population from Iraq, Iran, Afghanistan and Somalia in the age of 16-65 years in the Netherlands $(n=2,907)$.

Before moving on to the analysis and results sections of this paper, we wish to emphasise the main benefits and central drawback of this dataset. It is to our advantage that we have access to this large sample (especially compared to the total population of refugees in the Netherlands), as it contains extensive information on diverse topics and generates reliable and, to a large extent, generalisable results. However, given the cross-sectional character of the dataset, we also need to be cautious when drawing conclusions on the causality of the proposed mechanisms.

\section{Method}

Since we tested for mediating effects of a latent variable (mental health), we performed Structural Equation Modelling (SEM). We used Mplus for our path analyses since this program enables us to test models with categorical and dichotomous dependent variables. ${ }^{11}$ Compared to simple regression analysis, SEM provides better estimations. These are computed simultaneously for the model as a whole, whereas simple regression estimates are computed separately in relation to each endogenous variable. ${ }^{12}$ The use of SEM implies testing causal effects, but as the data is cross-sectional, it was not possible to test the direction of the relations between dependent and independent variables. Results are therefore reported as associations. Before estimating the structural model, the measurement model of the latent variable (mental health) was tested on measurement invariance to uncover possible cultural bias in the answering patterns.

\footnotetext{
$\overline{10}$ The dataset contained only a marginal number of invited refugees $(n=6)$. Since a different policy applies to this category of refugees, they are excluded from the analysis as well.

11 The weighted least-squares with mean and variance adjustment estimator is used. This is the default estimator of Mplus and the optimal choice for categorical outcomes, based on the work of Muthén, DuToit and Spisic (1997).

12 Thus, chance capitalisation, i.e. the chance that a reported significant association is based on coincidence, is reduced.
} 
Table 1 Migration history and socio-economic background of research population

\begin{tabular}{lllll}
\hline & Afghan & Iraqi & Iranian & Somali \\
\hline $\begin{array}{c}\text { Number in the } \\
\text { Netherlands }\end{array}$ & 38,000 & 52,000 & 31,000 & 27,000 \\
$\begin{array}{c}\text { Peaks of } \\
\text { migration }\end{array}$ & $1998-2001$ & $\begin{array}{c}\text { Early 1980s-end } \\
\text { 1990s 2002-2009 }\end{array}$ & 1979-early 1990s & 1990 2005-2009 \\
$\begin{array}{c}\text { Migration motive } \\
\text { Taliban regime: } \\
\text { political reason }\end{array}$ & $\begin{array}{c}\text { Fear of persecution } \\
\text { 'war on terrorism' } \\
\text { Mixed }\end{array}$ & $\begin{array}{c}\text { Regime Khomeini: } \\
\text { political reason } \\
\begin{array}{c}\text { demographic } \\
\text { background }\end{array}\end{array}$ & $\begin{array}{c}\text { Mostly from urban } \\
\text { middle class }\end{array}$ & $\begin{array}{c}\text { Young, single } \\
\text { men; widows; } \\
\text { minors without } \\
\text { their parents }\end{array}$ \\
\hline
\end{tabular}

References: Hessels 2000; Hessels 2002; Hessels and Wassie 2003; Nieuwhof and Mahamoud 2000

${ }^{a}$ In January 2010

We estimated two models which specify the expected effects of length of stay in asylum accommodation and residence status, including mental health as a potential mediator, on employment status and social benefits dependency (Model 1, $n=2,709)^{13}$ and occupational status and type of contract (Model 2, $n=950$ ), both controlled for relevant background characteristics. Model 2, to estimate the effects on occupational status and type of contract, is performed for a selection of employed respondents only. The number of valid respondents for the analysis of occupational status is thus considerably smaller compared to Model 1 . The indirect effects of mental health are tested using the Sobel test.

\section{Measures}

Dependent Variable: Socio-Economic Integration

This study uses four measures of socio-economic integration. First, employment status represents those currently employed ${ }^{14}(1)$ versus unemployed people ${ }^{15}(0)$. Social benefits dependency contrasts those receiving financial assistance ${ }^{16}$ (1) with those not receiving financial support from the state $(0)$. Then, all respondents who are employed have described their occupation. Based on Erikson and Goldthorpe (1992),

\footnotetext{
${ }^{13}$ One of the benefits of Structural Equation Modeling is that you can estimate the model for several dependent variables at once. This is why we tested the effects on employment and social benefits dependency within one model.

${ }^{14}$ For more than $12 \mathrm{~h}$ a week, as this is the Dutch definition for belonging to the employed population.

${ }^{15}$ We use the definition of net participation, thus inactive respondents (housewives, disabled and students) are included in this category.

${ }^{16}$ Social assistance ('bijstand'), unemployment benefit (WW) and/or disability/incapacity benefit (WAO).
} 
we distinguished five categories for occupational status ${ }^{17}$ (ranging on an ordinal scale from $1=$ low to $5=$ high). Originally they provided a seven-category system, but using Ganzeboom and Treiman (1996) we transferred these to a five-category system. Last, we also study the type of contract, distinguishing between temporary (0) and permanent (1) jobs. Employment and social benefits dependency represent two sides of the coin of socio-economic integration; in effect, self-sustainability versus state dependency. The occupational status and type of contract yield more insight into the economic integration of those who are employed. Together, these four variables indicate the degree to which refugees are successful on the Dutch labour market.

Independent Variables: Length of Stay in Asylum Accommodation and Residence Status

The length of stay in asylum accommodation is directly observed and measured in months. Outliers ${ }^{18}$ are imputed on the maximum $(n=49)$. Also, for additional analyses, four dummies are created: 1-12 months; 12-24 months; 3-5 years; and >5 years. The respondents were asked what their current legal status is. We constructed a dummy for temporary status, permanent status and used Dutch nationality as reference category.

\section{Mediator: Mental Health}

Three items measuring the extent to which respondents felt calm, sad and nervous in the last 4 weeks were used to construct the latent variable mental health. These items stem from the internationally used SF12 health survey ${ }^{19}$. The measurement model has a good $\mathrm{fit}^{20}$ [Comparative Fit Index $(\mathrm{CFI})=.99$; Root Mean Square Error of Approximation $($ RMSEA $)=.00]$; thus, we can state that these three items measure the construct 'mental health' properly. Then, based on the test for measurement invariance, we conclude that the factor loadings, intercepts and residual variances of the latent variable are the same across the four refugee groups. The BIC criterion ${ }^{21}$ of the structural equivalence model $(\mathrm{BIC}=26,646.283)$ is preferred over the unrestricted model $(\mathrm{BIC}=26,738.160)$. We can thus conclude that the latent variable mental health is cross-culturally validated.

\section{Control Variables}

To identify any differences between the refugee groups, dummies per ethnicity are included (Iranian=ref). Further, we control for gender (female=1), age, education (in eight categories, ranging from no education to university degree), language proficiency

\footnotetext{
${ }^{17}$ We only used those respondents who are salaried workers; self-employed $(n=143)$ are excluded.

${ }^{18}$ Stays longer than 8 years are defined as outliers.

${ }^{19}$ De SF 12 consists of 12 items that form a reliable measure of eight domains of health: mental health is one of these domains (Ware et al. 1996).

${ }^{20}$ For the assessment of the model fit, we use a combination of two fit indices. RMSEA values $<.05$ are considered to indicate a good fit. A CFI value of .90 or higher indicates strong correlation between the variables, which indicates a good fit.

${ }^{21}$ The BIC criterion is based on model fit and model complexity. It thus represents how much the model deviates from the reality taking into account the number of parameters and sample size. Models with lower values are preferred (Hagenaars 1990).
} 
(mean scale of problems with reading, writing and speaking Dutch; category $1=$ frequent problems $2=$ occasional problems and $3=$ no problems), length of stay in the Netherlands (log), age of migration, having a partner (1=partner at home, 2=partner abroad, ref $=$ single $)$ and reason for migration $(0=$ war, $1=$ fear of personal persecution, $2=$ family reunification). Lastly, a substantial share of the respondents in our dataset (90\%) arrived in the Netherlands prior to 2001 and was thus subject to the former asylum act. Unfortunately, the subsample of respondents who arrived after 2001 is relatively small $(n=248)$. We were thus not able to perform a comparative analysis between these timeframes; possible differences between the timeframes could just as well be due to composition effects as to the policy change. We therefore only include arrival after the New Aliens Act 2001 was enacted as a control variable. Summary statistics are presented in Table 2 .

\section{Results}

\section{Descriptive Results}

The average stay in asylum accommodation is about 21 months (Table 2). As expected, the bivariate relations show that a longer stay in asylum accommodation is positively associated with the risk of social benefits dependency and that it decreases employment chances, permanent job chances and refugees' occupational status (Table 3). Further, the descriptive results show that over $70 \%$ of the respondents have the Dutch nationality by the end of 2009 . Only $16 \%$ has a temporary status, but as expected, both the temporary and permanent status are positively related to social benefits dependency and negatively to employment, to having a permanent job and to occupational status (Table 3). Mental health correlates with the employment status and social benefits dependency on the one hand, and with the length of stay in asylum accommodation on the other (Table 3); this indicates the potential of this variable to function as a mediator in these relationships. An association between mental health and occupational status and type of contract is not found, however; it thus appears that mental health does not mediate the effect of duration stay in asylum accommodation on occupational status and type of contract. These descriptive findings also suggest that mental health does not function as a mediator in the relation between residence status and socio-economic integration, since no correlation between these is found. We perform Structural Equation Modelling in order to test whether these relations remain after controlling for several demographic characteristics. We furthermore test whether the stated effects are direct or mediated by mental health.

\section{Results from Structural Equation Modelling}

The model fit indices show a good model fit for both estimated models (Model 1, $\mathrm{CFI}=.99$, RMSEA=.01; Model 2, CFI=.98; RMSEA=.02). We expected the length of stay in asylum accommodation to have a detrimental effect on refugees' socioeconomic integration $(\mathrm{H} 1)$; also, we expected this effect to be partly mediated by mental health (H3). In line with former studies, the analyses show that mental health is an important predictor of socio-economic integration among the refugee groups under study. A good mental health is positively related to employment 
Table 2 Description of dependent, independent and control variables

\begin{tabular}{|c|c|c|c|c|c|}
\hline & $N$ & Min. & Max. & Mean & Std. dev. \\
\hline \multicolumn{6}{|l|}{ Dependent variables } \\
\hline Employed & 2,907 & 0 & 1 & .39 & \\
\hline Social benefits dependency & 2,907 & 0 & 1 & .39 & \\
\hline Occupational status & 1,150 & 1 & 5 & 2.23 & 1.05 \\
\hline Permanent job & 1,195 & 0 & 1 & .52 & \\
\hline \multicolumn{6}{|l|}{ Independent variables } \\
\hline $\begin{array}{l}\text { Length of asylum accommodation } \\
\text { (in months) }\end{array}$ & 2,907 & 1 & 96 & 21.4 & 22.2 \\
\hline \multicolumn{6}{|l|}{ Length of stay (ref $=1-12$ months) } \\
\hline 12-24 months & 2,907 & 0 & 1 & .21 & \\
\hline $3-5$ years & 2,907 & 0 & 1 & .18 & \\
\hline$>5$ years & 2,907 & 0 & 1 & .7 & \\
\hline \multicolumn{6}{|c|}{ Residence status (ref=Dutch nationality) } \\
\hline Temporary & 2,813 & 0 & 1 & .16 & \\
\hline Permanent & 2,813 & 0 & 1 & .09 & \\
\hline \multicolumn{6}{|l|}{ Intermediate variables } \\
\hline Mental health & 2,903 & 1 & 6 & 4.4 & 1.1 \\
\hline \multicolumn{6}{|l|}{ Control variables } \\
\hline \multicolumn{6}{|l|}{ Ethnicity (ref=Iranian) } \\
\hline Afghani & 2,907 & 0 & 1 & .27 & \\
\hline Iraqi & 2,907 & 0 & 1 & .24 & \\
\hline Somali & 2,907 & 0 & 1 & .28 & \\
\hline Female & 2,907 & 0 & 1 & .44 & \\
\hline Age (in years) & 2,907 & 15 & 65 & 35.6 & 11.9 \\
\hline Age of migration (in years) & 2,901 & 0 & 59 & 23.2 & 11.8 \\
\hline Education & 2,802 & 0 & 7 & 3.3 & 2.3 \\
\hline Language proficiency & 2,904 & 1 & 3 & 2.2 & .65 \\
\hline Length of stay (in years) & 2,907 & 1 & 30 & 12.4 & 4.1 \\
\hline \multicolumn{6}{|c|}{ Reason of migration (ref=family reunification) } \\
\hline War & 2,907 & 0 & 1 & .46 & \\
\hline Fear of personal persecution & 2,907 & 0 & 1 & .42 & \\
\hline \multicolumn{6}{|l|}{ Partner (ref=single) } \\
\hline Partner in the household & 2,907 & 0 & 1 & .47 & \\
\hline Partner outside the household & 2,907 & 0 & 1 & .09 & \\
\hline Aliens Act 2001 & 2,907 & 0 & 1 & .09 & \\
\hline
\end{tabular}

chances and negatively associated with the propensity for social benefits dependency (Fig. 2). Furthermore, for both employment status and social benefits dependency the Sobel test ${ }^{22}$ shows a significant indirect effect of the length of stay in

\footnotetext{
${ }^{22}$ This is used to test whether the indirect effect of the independent variable on the dependent variable through the mediator variable is significant.
} 
Table 3 Bivariate relations between post-migration stressors, mental health and socio-economic integration measures

\begin{tabular}{llllll}
\hline & Employed & $\begin{array}{l}\text { Social benefits } \\
\text { dependency }\end{array}$ & $\begin{array}{l}\text { Occupational } \\
\text { status }\end{array}$ & $\begin{array}{l}\text { Permanent } \\
\text { job }\end{array}$ & $\begin{array}{l}\text { Mental } \\
\text { health }\end{array}$ \\
\hline Length stay asylum accommodation & $-.05^{*}$ & $.04 *$ & $-.08^{* *}$ & $-.12 * *$ & $-.08^{* *}$ \\
Temporary status & $-.17^{* *}$ & $.14^{* *}$ & $-.12^{* *}$ & $-.18^{* *}$ & .01 \\
Permanent status & $-.08^{* *}$ & $.08^{* *}$ & $-.10^{* *}$ & $-.07^{*}$ & -.02 \\
Dutch nationality & $.20^{* *}$ & $-.18^{* *}$ & $.16^{* *}$ & $.19^{* *}$ & .01 \\
Mental health & $.18^{* *}$ & $-.24^{* *}$ & .02 & -.00 & \\
\hline
\end{tabular}

${ }^{*} p<.05 ; * * p<.01$

asylum accommodation via mental health, in the expected direction. Thus, a longer stay in asylum accommodation has a negative effect on perceived mental health which in turn negatively affects employment chances and positively affects the propensity for social benefits dependency. These indirect effects gain significance when staying in asylum accommodation for longer than five years $(\beta=-.06 ; \beta=.06)$. These findings thus partly support hypothesis 3; after a stay of 5 years or longer in asylum accommodation, socioeconomic integration seems to be hampered by mental health problems. Contrary to our expectation $(H 1)$, we found a small positive association between staying 3-5 years in asylum accommodation and employment status. The expected direct and indirect effects in the model for length of stay in asylum accommodation on occupational status and type of contract were all found to be insignificant (not shown).

Then, we expected that having a refugee status (both temporary and permanent), compared to having the Dutch nationality, would negatively affect the socioeconomic integration of refugees $(H 2)$. Indeed, Fig. 2 shows that having a temporary residence status is negatively related to the propensity for employment $(b=-.10)$ and is positively associated with the propensity for social benefits dependency $(b=.06)$. Thus, getting a job is harder for refugees who hold a temporary status compared to those who hold the Dutch nationality. Moreover, the propensity for having a permanent job is smaller for those who hold a temporary residence status $(b=-.11$, not shown). Refugees with a temporary status are also more likely to be dependent on social welfare benefits. For employment, the same effect, although weaker, is found for refugees holding a permanent residence status $(b=-.05)$. Clearly, having a refugee status hampers the socio-economic integration of refugees. As expected, this effect is stronger for refugees with a temporary residence status. However, no effects of residence status were found on refugees' occupational status. Hypothesis $2 \mathrm{a}$ and $2 \mathrm{~b}$ are thus largely corroborated. In congruence with the descriptive results, we did not find support for the hypothesis that mental health also functions as a mediator in the relation between residence status and socio-economic integration (H4).

When inspecting the control variables, we conclude that length of stay in the Netherlands is positively related to employment chances ${ }^{23}$. This finding is in line with

\footnotetext{
${ }^{23}$ This association is no longer significant when we add language proficiency to the model. This makes sense since the acquisition of language skills is also time-dependent.
} 


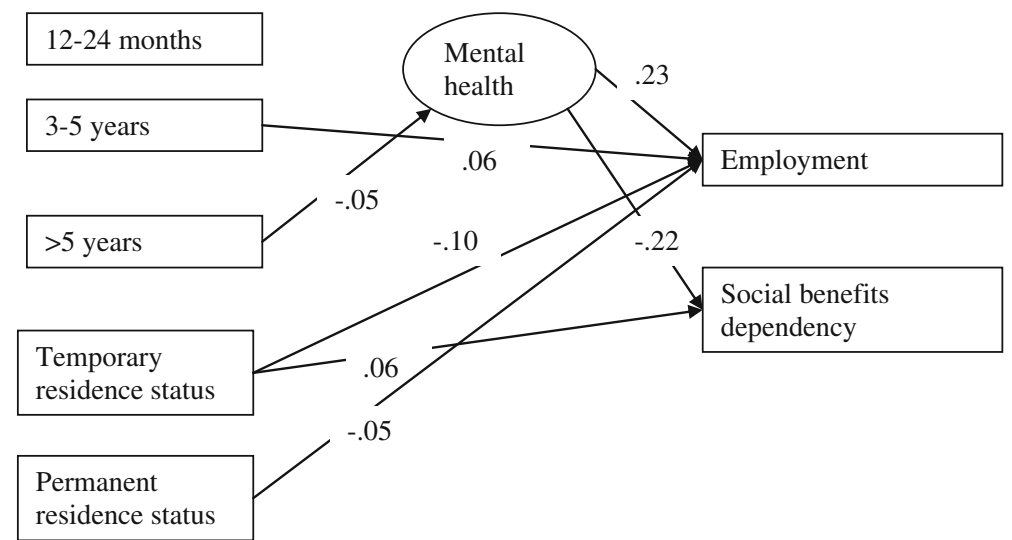

Fig. 2 The effects of length of stay in asylum accommodation and residence status on refugee employment and social benefits dependency; ( $N=2,709$, controlled model, standardized coefficients). Only significant arrows $(p<.05)$ are displayed; the standardized coefficients of the control variables are presented in Table 4

classical assimilation theory that argues that immigrants need time to regain the necessary resources for successful integration. Finally, education, language proficiency and having a partner within the household are positively related to socio-economic integration (Table 4). This confirms findings from previous studies that social and cultural resources are also important to understand and explain the socio-economic integration of refugees. This study shows, however, that mental health and residence status are important predictors for socio-economic integration as well, since these effects remain after controlling for all the mentioned relevant background characteristics.

Table 4 Standardised coefficients of control variables in model 1 and model 2

\begin{tabular}{|c|c|c|c|c|c|}
\hline & $\begin{array}{l}\text { Mental } \\
\text { health }\end{array}$ & Employed & $\begin{array}{l}\text { Social } \\
\text { benefits } \\
\text { dependency }\end{array}$ & $\begin{array}{l}\text { Occupational } \\
\text { status }\end{array}$ & $\begin{array}{l}\text { Permanent } \\
\text { job }\end{array}$ \\
\hline Afghan $($ Iranian=ref) & $.07 *$ & $-.06^{*}$ & .01 & $-.10^{*}$ & -.04 \\
\hline Iraqi & .05 & $-.09 * *$ & -.02 & $-.08^{*}$ & $-.13 * *$ \\
\hline Somali & $.21 * *$ & -.05 & $.22 * *$ & $-.13^{* *}$ & -.03 \\
\hline Female & $-.11 * *$ & $-.25 * *$ & $.07 * *$ & .29 & -.30 \\
\hline Age & -.12 & -.03 & -.20 & -.07 & .01 \\
\hline Age migration & -.10 & -.02 & $.65^{* *}$ & -.33 & .38 \\
\hline Education & -.03 & $.14 * *$ & $-.07 * *$ & $.36^{* *}$ & -.03 \\
\hline Length of stay (log) & -.03 & .20 & .12 & -.10 & .39 \\
\hline Language proficiency & $.19^{* *}$ & $.09 * *$ & $-.15^{* *}$ & $.15^{* *}$ & .06 \\
\hline War (family reunification=ref) & -.02 & -.02 & .07 & .02 & $.17 *$ \\
\hline Fear of political persecution & .02 & $.07 *$ & .03 & .08 & $.25^{* *}$ \\
\hline $\begin{array}{l}\text { Partner in the household } \\
\quad(\text { single }=\text { ref })\end{array}$ & $.14^{* *}$ & $.25 * *$ & $-.20 * *$ & $.10^{* *}$ & $.16^{* *}$ \\
\hline Partner outside the household & -.02 & $.11 * *$ & -.03 & .07 & -.00 \\
\hline Refugee Act 2001 & -.02 & .03 & .05 & -.06 & .07 \\
\hline
\end{tabular}

$* p<.05 ; * * p<.01$ 


\section{Conclusion and Discussion}

In this study, we examined the impact of two policy-related post-migration stressors on the socio-economic integration of refugees in the Netherlands: the length of stay in asylum accommodation and the residence status granted. We specifically highlighted the possible mediating function of mental health. The analyses turn up interesting results, both theoretically and for policy purposes. First, we found that having stayed in asylum accommodation for more than 5 years negatively affects refugees' mental health which in turn hampers their socio-economic integration. It thus does seem that insecurity about the future and reduced confidence due to a long stay in asylum accommodation affects refugees' chances of success on the Dutch labour market in the long run. This provides support for Hobfoll's theory (2001) that the postmigration experience can result in stress and disappointment when refugees fail to achieve the expected return of their flight.

It should be noted that the size of this indirect effect is modest. One could argue that time heals wounds, so that the negative effect of staying in asylum accommodation will fade over time. However, in this study we show that, even though the average length of stay in the Netherlands is 12.5 years, staying in asylum accommodation for an extremely lengthy period ( $>5$ years) continues to have a detrimental effect on their current mental health and success in Dutch society. This finding supports the idea that the responsibility of the receiving society to facilitate integration is not to be underestimated and should be considered in both research and practice. It moreover shows that integration starts upon arrival and has long-term outcomes.

We may furthermore conclude that this finding accords with the aims of the New Aliens Act: shorter asylum procedures appear to benefit refugees' socio-economic integration. However, we should be cautious with respect to other potential drawbacks of the shorter asylum procedure. For example, gathering the necessary information within the set period of 6 months to decide whether someone's fear of persecution is legitimate is highly problematic (Terlouw and Zwaan 2011).

The second main finding is that residence status has a clear direct effect on socioeconomic integration. Having a temporary refugee status hampers socio-economic integration, compared to refugees who have been granted the Dutch nationality. This provides support for the resources-based model (Ryan et al. 2008), which assumes that citizenship is a prerequisite to successful refugee integration. In terms of Hobfoll (2001), a temporary residence status is a constraint to (re)gain the necessary resources for successful integration. The current policy paradigm, in which citizenship is viewed as the 'crown' that completes the integration process (Ersanilli 2010), may thus be counterproductive. As this paper shows, having a secure residence status, preferably citizenship, may be necessary to be able to integrate in Dutch society in the first place.

In line with Hobfoll (2001), this study confirms the importance of social and cultural resources to refugees' socio-economic integration. Education and language proficiency are strong predictors of success in Dutch society. Further, the results show some interesting differences between refugee groups. The Iranian group clearly achieves the best socio-economic integration, while the Somali group seems to encounter the most obstacles in their integration process. In this article, we approached and analysed the refugees as one coherent group, based on their common migration motive: flight. Future research could further investigate and explain differences in integration success 
between refugee groups. The impact of home country characteristics should then be taken into account as well.

Again, we want to emphasise that in this study we used cross-sectional data, so no causal relations can be statistically determined between the independent and dependent variables. It is in fact not unlikely that an inverse relationship between socio-economic integration and mental health exists as well. Having a job can instil confidence and open up prospects, which can benefit refugees' state of mind. However, in this article we modestly argue, although theoretically grounded, that mental health can be affected by post-migration experiences which in the long run can affect socio-economic integration. Future research might fruitfully pursue a longitudinal approach to shed more light on this association.

Also, in this article we focused on the socio-economic dimension of integration, while the literature clearly distinguishes different dimensions of integration, including social and cultural integration. Further studies might elaborate on these other dimensions with regard to refugee groups in the Netherlands and elsewhere.

To conclude, this study demonstrates the importance of post-migration stressors and of mental health as a personal resource to understand refugee integration, in addition to the frequently demonstrated impact of traumatic experiences. It also adds the importance of residence status as a resource to the explanatory framework of refugee integration. Lastly, this paper provides a starting point for public debate on the contradiction between the demand to integrate and participate in Dutch society, while the level of security and the opportunities offered by the current refugee statuses to do so are limited.

\section{References}

Ager, A., \& Strang, A. (2008). Understanding integration: a conceptual framework. Journal of Refugee Studies, 21(2), 166-191.

Beiser, M. (2006). Longitudinal research to promote effective refugee resettlement. Transcultural Psychiatry, 43(1), 56-71.

Berry, J. W., Kim, U., Minde, T., \& Mok, D. (1987). Comparative studies of acculturative stress. International Migration Review, 21(3), 491-511.

Blom, S. (2004). Labour market integration of refugees in Norway under changing macro-economic conditions. Journal of International Migration and Integration, 5(1), 1-31.

Castles, S., Korac, M., Vasta, E., \& Vertovec, S. (2002). Integration: mapping the field. Report of a Project carried out by the University of Oxford Centre for Migration and Policy Research and Refugee Studies Centre. London: Home Office Online Report 28/03, http://webarchive.nationalarchives.gov.uk/ 20110220105210/http://rds.homeoffice.gov.uk/rds/onlinepubs1.html (downloaded 6 July 2011).

Dagevos, J. (2001). Perspectief op integratie: over de sociaal-culturele en structurele integratie van etnische minderheden in Nederland. Den Haag: Wetenschappelijke Raad voor het Regeringsbeleid.

De Haan, W., \& Althoff, M. (2002). Vreemd en verdacht. Een verkennend onderzoek naar criminaliteit in en om asielzoekerscentra. Rijksuniversiteit Groningen.

De Vroome, T., \& Van Tubergen, F. (2010). The employment experience of refugees in the Netherlands. International Migration Review, 44(2), 376-403.

Dourleijn, E. (2010). Survey Integratie Nieuwe Groepen 2009: verantwoording van de opzet van een survey onder Afghaanse, Iraanse, Iraakse, Somalische, (kort verblijvende) Poolse en Chinese Nederlanders en een autochtone Nederlandse vergelijkingsgroep. Den Haag: Sociaal en Cultureel Planbureau.

Dourleijn, E., \& Dagevos, J. (2011). Vluchtelingengroepen in Nederland: Over de integratie van Afghaanse, Iraanse, Iraakse en Somalische migranten. Den Haag: Sociaal en Cultureel Planbureau. 
Engbersen, G. (2003). Spheres of integration. In R. Sackmann, B. Peters, \& T. Faist (Eds.), Identity and integration: migrants in Western Europe (pp. 59-76). Aldershot/Burlington: Ashgate.

Erikson, R., \& Goldthorpe, J. H. (1992). The constant flux: a study of class mobility in industrial societies. Oxford: Clarendon.

Ersanilli, E. (2010). Comparing integration. Host culture adoption and ethnic retention among Turkish immigrants and their descendants in France, Germany and the Netherlands. Amsterdam: VU University.

Esser, H. (2004). Does the "new" immigration require a "new" theory of intergenerational integration? International Migration Review, 38, 1126-1159.

Feller, E. (2005). Refugees are not migrants. Refugee Survey Quarterly, 24(4), 27-35.

Ganzeboom, H. B. G., \& Treiman, D. J. (1996). Internationally comparable measures of occupational status for the 1988 international standard classification of occupations. Social Science Research, 25(3), 201239.

Ghorashi, H. (2005). Agents of change or passive victims: the impact of welfare states (the case of the Netherlands) on refugees. Journal of Refugee Studies, 18(2), 181-198.

Hagenaars, J. A. (1990). Categorical longitudinal data. Newbury Park: Sage.

Hessels, T. (2000). Somaliers in Nederland. Een profiel. Den Haag: ministerie van Binnenlandse Zaken en Koninkrijksrelaties.

Hessels, T. (2002). Iraniers in Nederland. Een profiel. Den Haag: ministerie van Binnenlandse Zaken en Koninkrijksrelaties.

Hessels, T., \& Wassie, F. (2003). Afghanen in Nederland. Een profiel. Den Haag: ministerie van Binnenlandse Zaken en Koninkrijksrelaties.

Hobfoll, S. E. (2001). The influence of culture, community, and the nested-self in the stress process: advancing conservation of resources theory. Applied Psychology: An International Review, 50, 337-421.

Jahoda, M. (1982). Employment and unemployment: a social-psychological analysis. Cambridge: Cambridge University Press.

Jorden, S., Matheson, K., \& Anisman, H. (2009). Supportive and unsupportive social interactions in relation to cultural adaptation and psychological distress among Somali refugees exposed to collective or personal trauma. Journal of Cross-Cultural Psychology, 40(5), 853-874.

Kofman, E. (2002). Contemporary European migrations, civic stratification and citizenship. Political Geography, 21(8), 1035-1054.

Laban, C. J., Gernaat, H. B. P. E., Komproe, I. H., Schreuders, B. A., \& De Jong, J. T. V. M. (2004). Impact of a long asylum procedure on the prevalence of psychiatric disorders in Iraqi asylum seekers in the Netherlands. The Journal of Nervous and Mental Disease, 192(12), 843-851.

Lomba, S. D. (2010). Legal status and refugee integration: a UK perspective. Journal of Refugee Studies, 23(4), 415-436.

Mestheneos, E., \& Ioannidi, E. (2002). Obstacles to refugee integration in the European Union member states. Journal of Refugee Studies, 15, 304-320.

Momartin, S., Steel, Z., Coello, M., Aroche, J., Silove, D. M., \& Brooks, R. (2006). A comparison of the mental health of refugees with temporary versus permanent protection visas. The Medical Journal of Australia, 185(7), 357-361.

Morris, L. (2003). Managing contradictions: civic stratification and migrants' rights. International Migration Review, 37(1), 74-100.

Morris, L. (2012). Rights, recognition and judgement: reflections on the case of welfare and asylum. The British Journal of Politics and International Relations, 14(1), 39-56.

Muthén, B. O., Dutoit, S. H. C., \& Spisic, D. (1997). Robust inference using weighted least squares and quadratic estimating equations in latent variable modeling with categorical and continuous outcomes. Accepted for publication in Psychometrika.

Nieuwhof, A., \& Mahamoud, A. (2000). Communicatie, sleutel en participatie. De Somalische gemeenschap in Nederland. Den Haag: ministerie van Binnenlandse Zaken en Koninkrijksrelaties.

Phillimore, J. (2011). Refugees, acculturation strategies, stress and integration. Journal of Social Policy, 40(3), 575-593.

Potocky-Tripodi, M. (2003). Refugee economic adaptation: theory, evidence and implications for policy and practice. Journal of Social Service Research, 30(1), 63-91.

Ryan, D., Dooley, B., \& Benson, C. (2008). Theoretical perspectives on post-migration adaptation and psychological well-being among refugees: towards a resource-based model. Journal of Refugee Studies, 21(1), 1-18.

Snel, E., Engbersen, G., \& Leerkes, A. (2006). Transnational involvement and social integration. Global Networks, 6, 285-308. 
Takeda, J. (2000). Psychological and economic adaptation of Iraqi adult male refugees: implications for social work practice. Journal of Social Service Research, 26(3), 1-21.

Terlouw, A., \& Zwaan, K. (2011). Tijd en asiel: 60 jaar Vluchtelingenverdrag. Deventer: Kluwer.

Vermeulen, H., \& Penninx, R. (2000). Immigrant integration: the Dutch case. Amsterdam: Het Spinhuis.

Ware, J., Jr., Kosinski, M., \& Keller, S. D. (1996). A 12-item Short-Form Health Survey: construction of scales and preliminary tests of reliability and validity. Medical Care, 34, 220-33.

Waxman, P. (2001). The economic adjustment of recently arrived Bosnian, Afghan and Iraqi refugees in Sydney Australia. International Migration Review, 35(2), 472-505. 